\title{
GC-MS Analysis of Volatile Organic Constituents of Traditionally Used Medicinal Plants from the Western Ghats of India: Blumea lanceolaria (Roxb.) Druce., Heliotropium indicum $L$. and Triumfetta rhomboidea Jacq.
}

\author{
Rajesh K. Joshi* \\ Department of Phytochemistry, ICMR-National Institute of Traditional Medicine, Belagavi, Karnataka-590 \\ 010, India.
}

*Corresponding author: Rajesh K. Joshi, email: joshirk_natprod@yahoo.com

Received September $9^{\text {th }}, 2019$; Accepted January $8^{\text {th }}, 2020$.

DOI: http://dx.doi.org/10.29356/jmcs.v64i2.1093

\begin{abstract}
The present study explored essential oil constituents of the medicinal plants used in traditional medicine and growing wild in the Western Ghats region of India, which is one of the 34 global biodiversity hotspots. The hydro distilled essential oils of Blumea lanceolaria (Roxb.) Druce. (Asteraceae), Heliotropium indicum L. (Boraginaceae) and Triumfetta rhomboidea Jacq. (Tiliaceae) were analyzed using gas chromatography equipped with a flame ionization detector (GC-FID) and gas chromatography coupled with mass spectroscopy (GC/MS). Thirty-six, twenty-seven, and fifty constituents were identified from the essential oils of $B$. lanceolaria, $H$. indicum, and $T$. rhomboidea, respectively comprising $97.3 \%$ (B. lanceolaria), $98.2 \%$ (H. indicum) and $97.6 \%$ (T. rhomboidea) of the total oil constituents. The major compounds of B. lanceolaria, $H$. indicum, and $T$. rhomboidea were identified as $\beta$-pinene $(82.3 \%)$, methyl salicylate $(54.3 \%)$, and $\beta$ caryophyllene $(28.9 \%)$, respectively. The essential of $B$. lanceolaria was found to be rich in monoterpene hydrocarbons $(90.4 \%)$, while $H$. indicum and T. rhomboidea oils were rich in phenyl derivative $(72.8 \%)$ and sesquiterpene hydrocarbons (69.5\%) type constituents, respectively. The common compounds viz., terpin-4-ol and eugenol were identified in the essential oils of B. lanceolaria, H. indicum, and T. rhomboidea.

Keywords: Blumea lanceolaria (Roxb.) Druce.; Heliotropium indicum L; Triumfetta rhomboidea Jacq.; terpin4-ol; eugenol; GC/MS.

Resumen. El presente estudio exploró los componentes de los aceites esenciales de plantas medicinales utilizadas en la medicina tradicional y de plantas silvestres que crecen en la región occidental de Ghats, India, que es uno de los 34 puntos críticos de la biodiversidad mundial. Los aceites esenciales hidro destilados de Blumea lanceolaria (Roxb.) Druce. (Asteraceae), Heliotropium indicum L. (Boraginaceae) y Triumfetta rhomboidea Jacq. (Tiliaceae) se analizaron mediante cromatografía de gases equipada con un detector de ionización de flama (GC-FID) y por cromatografía de gases acoplada con espectrometría de masas (GC / MS). Se identificaron treinta y seis, veintisiete y cincuenta componentes de los aceites esenciales de $B$. lanceolaria, H. indicum y T. rhomboidea, respectivamente, que comprenden $97.3 \%$ (B. lanceolaria), 98.2\% (H. indicum) y $97.6 \%$ ( $T$. rhomboidea) del total de los constituyentes del aceite esencial. Los principales compuestos de $B$. lanceolaria, H. indicum y T. rhomboidea se identificaron como $\beta$-pineno (82.3\%), salicilato de metilo (54.3\%) y $\beta$-cariofileno (28.9\%), respectivamente. Se observó que el aceite esencial de B. lanceolaria era rico en hidrocarburos monoterpénicos $(90.4 \%)$, mientras que los aceites esenciales de $H$. indicum y T. rhomboidea eran ricos en derivados de fenilo (72.8\%) e hidrocarburos sesquiterpénicos $(69.5 \%)$, respectivamente. Los compuestos comunes, a saber, terpin-4-ol y eugenol, se identificaron en los aceites esenciales de $B$. lanceolaria, H. indicum y T. rhomboidea.
\end{abstract}


Palabras clave: Blumea lanceolaria (Roxb.) Druce.; Heliotropium indicum L.; Triumfetta rhomboidea Jacq.; Terpin-4-ol; eugenol; GC / MS.

\section{Introduction}

"Herbal medicines are in widespread use and although many believe that herbal medicines are safe, and often used in combination are drawn from plant sources with their own variability in species, growing conditions, and biologically active constituents" [1]. "The essential oils are natural products that plants produce for their own needs other than nutrition (i.e. protection or attraction). In general, they are complex mixtures of organic compounds that give characteristic odor and flavor to the plants. They are mainly made up of monoterpenes and sesquiterpenes whose main metabolic pathway is through mevalonate leading to sesquiterpenes and from methyl-erythritol leading to monoterpenes" [2]. The exploration of traditional knowledge for the cure to common diseases is attractive since antiquity. The medicinal plants are responsible for most of the medicine and food used in modern society [3]. In India, about70 percent of the rural population depends on the traditional Ayurvedic system of medicine. Most healers/practitioners of the traditional systems of medicine prepare formulations by their own recipes and dispense to the patients. The Western Ghats region is one of the 34 global biodiversity hotspots [4] which covers the Northwest Karnataka region.

Blumea lanceolaria (Roxb.) Druce. is belongs to the family Asteraceae. The leaves of B. lanceolaria are aromatic and used as a flavoring agent for the food. In traditional medicine, the leaves are used for the treatment of bronchitis, aphthae and asthma [5]. B. lanceolaria locally known as 'Buarze' in Mizoram, India and in folklore medicine this plant is used as an anti-cancer agent and leaves juice is useful for wound healing, chronic ulcers and infusion of leaves to control dysentery [6]. In the previous report, essential oil of $B$. lanceolaria has been reported a high amount of $p$-cymene [7] and methyl thymol [8] from India and Vietnam, respectively.

Heliotropium indicum L. of the family Boraginaceae is a high valued medicinal plant known in Ayurveda as Hastishundi Shrihastini or Vrischikaali and distributed throughout India [9]. This is one of the most widely used herbs in the Ayurvedic medicine of India and some other countries for the treatment of liver diseases [10]. In traditional medicine, this plant is used as a local application for ulcers, wounds, sores, gum boils and skin affections [9]. The tribal community of Phulbani district of Odisha, India use the leaf paste of $H$. indicum over fresh cuts and wounds and claim for its promising activity [11] and scientifically reported wound healing activity on animals [11,12]. The decoction of leaves is used in urticaria and fevers and root is used for the treatment of coughs. Small doses of flower decoction are used for emmenagogue, while abortifacient in large doses [9]. The pharmacological activities like gastroprotective, antimicrobial, [13], anti-inflammatory [14], activities have been reported from various solvent extracts of $H$. indicum. The alkaloids viz., indicine [10], indicinine [15], helindicine, lycopsamine [16], pestalamide B, glycinamide,N-(1-oxooctadecyl) glycyl-Lalanylglycyl-L-histidyl [17] and indicine-N-oxide [18] have been isolated from $H$. indicum. The major volatile compounds phytol, 1-dodecanol, and $\beta$-linalool have been reported from Thailand and the oil showed significant anti-tuberculosis activity against Mycobacterium tuberculosis H37Ra in the Alamar blue assay system with a MIC of $20.8 \mu \mathrm{g} / \mathrm{mL}[19]$. Another report from Nigeria reported phenylacetaldehyde, $(E)$-2-nonenal and $(E, Z)-$ 2-nonadienal and hexahydrofarnesylacetone [20] were the major constituents.

Triumfetta rhomboidea Jacq. of the family Tiliaceae is commonly known in English as 'Burbush' or 'Burweed'; in Ayurveda as 'Jhinjhireetaa' or 'Gippit' and in Karnataka 'Bankitutturi' and distributed throughout tropical and subtropical India, up to $1200 \mathrm{~m}$ in the Himalayas [9]. The plant is known as a weed, but a number of medicinal properties have been described for its different parts. In eastern Africa, $T$. rhomboidea is used in folk medicine for its abortive properties on the gravid mammalian uterus [21] and treatment of cancer among the tribal population in Kolli Hills, South India [22]. In traditional medicine, the bark and leaves of this plant are used for the treatment of diarrhea and dysentery [9]. Some pharmacopeia in eastern Africa described the uses of powdered leaves as an infusion for the treatment of anemia. In Kenya, this species is crushed and employed in massage to relieve labor pain. The infusion solution from its pounded roots is utilized as an anti-venom by applying to the bite area. In Rwanda, T. rhomboidea is used to treat pneumonia, 
otitis, and diarrhea [23]. Various extracts of T. rhomboidea have been reported to possess cytotoxic [23], antioxidant [24] and antimicrobial [21] activities. A new compound triumfettamide $\mathrm{B}$, along with lupeol, $\beta$ sitosterol, stigmasterol, oleanolic acid, maslinic acid, $\beta$-sitosterol glucopyranoside, and trans-tiliroside have been isolated and identified from T. rhomboidea [23]. The aerial parts of $T$. rhomboidea have been reported trans- $\beta$-caryophyllene, kessane and caryophyllene oxide as the major constituents [21].

This communication presents the essential oil composition of the different species of the traditional herbs viz., B. lanceolaria, H. indicum and T. rhomboidea (Fig. 1) growing Western Ghats region of India with the aim of possible utilization of the oil and demarcation of its terpenoid profile.

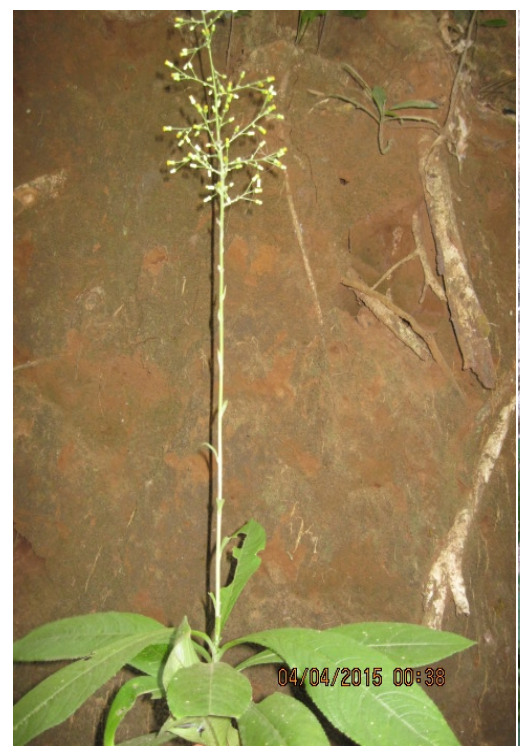

B. lanceolaria

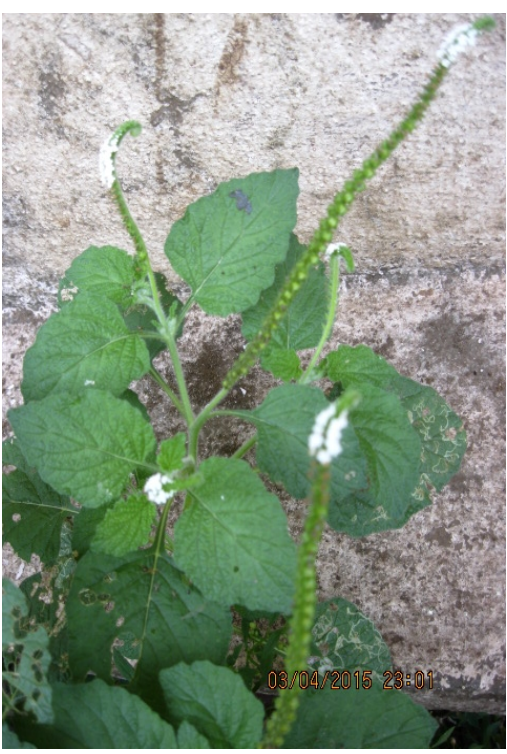

H. indicum

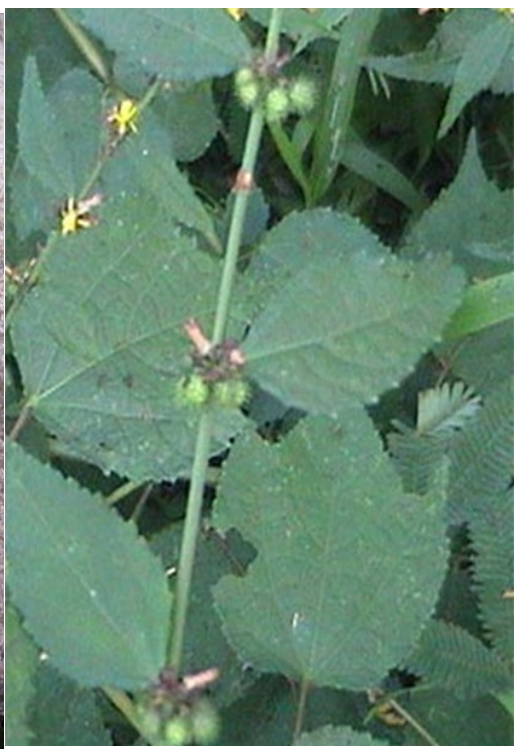

T. rhomboidei

Fig. 1. Plants species of the traditional herbs growing in Western Ghats of North West Karnataka.

\section{Experimental}

\section{Plant material}

The leaves of $B$. lanceolaria and $H$. indicum were collected from Yana (N 14.51117; E 74.53061) forests of the Western Ghats in Uttara Kannada district, Karnataka, India, at a height of $\sim 610 \mathrm{~m}$. The aerial parts with raw seeds of $T$. rhomboidea were collected from Tilari of district Kholapur (N 15.79952; E 74.17441), Maharashtra, India, at a height of $\sim 760 \mathrm{~m}$. The plants were identified at ICMR-National Institute of Traditional Medicine (NITM), Belagavi, where the herbarium specimens have been deposited (B. lanceolaria: RMRC-1313; H. indicum: RMRC-1317; T. rhomboidea; RMRC-1333).

\section{Isolation of essential oil}

The dried leaves of B. lanceolaria (450 g), H. indicum (700 g) and fresh raw seeds of T. rhomboidea $(250 \mathrm{~g})$ were hydro-distilled separately for $3 \mathrm{~h}$ using a Clevenger type apparatus. The obtained oil was dried over anhydrous sodium sulfate and stored at $-4{ }^{\circ} \mathrm{C}$ until further analysis. The yield of the oil was $0.02 \% \mathrm{w} / \mathrm{w}$ for B. lanceolaria; $0.01 \% \mathrm{w} / \mathrm{w}$ for $H$. indicum and $0.15 \% \mathrm{w} / \mathrm{w}$ for $T$. rhomboidea. 


\section{Chromatographic analysis}

The chemical composition of the essential oils of B. lanceolaria, H. indicum, and T. rhomboidea (1\% solution of essential oil in equal ratio of $n$-hexane: dichloromethane) were analyzed by using a Gas Chromatograph (GC) (Varian 450 fitted with a fused silica capillary column BP-1 (100\% dimethyl polysiloxane; SGE Analytical Science), $30 \mathrm{~m} \times 0.25 \mathrm{~mm}$ i.d., $0.25 \mu \mathrm{m}$ film thickness) under the experimental conditions reported earlier [25-27]. The oven temperature was programmed from $60-220^{\circ} \mathrm{C}$ at $3^{\circ} \mathrm{C} / \mathrm{min}$, using nitrogen as a carrier gas. The injector and the detector (FID) temperature were set at $230^{\circ} \mathrm{C}$ and $240^{\circ} \mathrm{C}$, respectively. Gas Chromatography-Mass Spectrometer (GC-MS) analysis was employed as a Thermo Scientific Trace Ultra GC interfaced with a Thermo Scientific ITQ 1100 mass spectrometer fitted with a BP-1 (100\% dimethylpolysiloxane; SGE Analytical Science) fused silica capillary column $(30 \mathrm{~m} \times 0.25 \mathrm{~mm} ; 0.25 \mu \mathrm{m}$ film thickness). The oven temperature range was programmed from $60-220^{\circ} \mathrm{C}$ at $3{ }^{\circ} \mathrm{C} / \mathrm{min}$ and helium was used as carrier gas at $1.2 \mathrm{~mL} / \mathrm{min}$ for analysis. The injector temperature was set at $230^{\circ} \mathrm{C}$, and the injection volume was $0.1 \mu \mathrm{L}$ in $n$-hexane, with a split ratio of 1:50. MS were taken at $70 \mathrm{eV}$ with a mass range of $m / z 40-450$ and other parameters used were those reported earlier [28-30]. Identification of constituents were done on the basis of Retention Index (RI, determined [Linear Temperature programmed analysis was used with the formula RI $=$ $100 \times\left[\left(t_{R i}-v\right)-\left(t_{R Z}-v\right) /\left(t_{R}(Z+1)-v\right)-\left(t_{R Z}-v\right)+Z\right]$ where $t_{R i}=$ retention time of sample peak; $v=$ column void time; $\mathrm{t}_{\mathrm{RZ}}=$ retention time of $n$-alkane peak eluting immediately before sample peak; $\mathrm{t}_{\mathrm{R}(\mathrm{Z}+1)}=$ retention time of $n$-alkane peak eluting immediately after sample peak; $Z$ = carbon number of $n$-alkane peak eluting immediately before sample peak [31] with reference to homologous series of $n$-alkanes $\mathrm{C}_{8}-\mathrm{C}_{25}$ under identical experimental conditions on BP-1 column), MS library search NIST 08 MS Library (Version 2.0 f; Thermo Fisher Scientific Austria) and WILEY MS $9^{\text {th }}$ Edition (Thermo Fisher Scientific Austria), and by comparing with the MS literature data and co-injection of commercial samples from Sigma-Aldrich, India ( $\geq 98 \%$ purity). The relative amounts of individual components were calculated based on the GC peak area (FID response) without using a correction factor.

\section{Results and discussion}

Chemical components of essential oils from B. lanceolaria, H. indicum, and T. rhomboidea have been presented in Table 1 in elution order from the BP-1 column, along with the percentage composition of each component and its retention index. Thirty-six, twenty-seven, and fifty constituents from the essential oils of $B$. lanceolaria, $H$. indicum, and T. rhomboidea, respectively were identified according to their mass spectra and their relative retention indices determined in a nonpolar stationary phase capillary column. The essential oils of B. lanceolaria, H. indicum, and T. rhomboidea comprising $97.3 \%, 98.2 \%$, and $97.6 \%$, respectively of the total oil constituents. The major compound of the essential oil of $B$. lanceolaria was identified as $\beta$-pinene (82.3\%) along with other minor constituents terpin-4-ol (4.1\%), $\gamma$-terpinene $(2.5 \%)$ and sabinene $(2.2 \%)$. The oil was found to be rich in monoterpene hydrocarbons $(90.4 \%)$, followed by oxygenated monoterpenes $(6.5 \%)$ and phenyl derivatives $(0.2 \%)$. The major constituent of the essential oil of $H$. indicum was methyl salicylate (54.3\%). The other minor constituents were sabinene (7.9\%), eugenol (6.3\%) and cis-calamenene (4.7\%). The oil was found to be rich in phenylpropanoid type constituents $(72.8 \%)$, followed by monoterpene hydrocarbons $(17.6 \%)$, sesquiterpene hydrocarbon $(6.6 \%)$, oxygenated monoterpene $(0.9 \%)$ and oxygenated sesquiterpene $(0.3 \%)$. The major compound of the essential oil of $T$. rhomboidea was identified as $\beta$-caryophyllene (28.9\%). The other minor constituents were $\alpha$-humulene (8.5\%), germacrene D (6.9\%), cis-calamene-10-ol (6.5\%), $\alpha$ cadinol $(5.4 \%)$ and $\delta$-cadinene (4.8\%). The oil was found to be rich in sesquiterpene hydrocarbons $(69.5 \%)$, followed by oxygenated sesquiterpenes (21.5\%), oxygenated long-chain hydrocarbons (3.7\%), monoterpene hydrocarbon (1.6\%), and phenyl derivatives (1.3\%) type constituents. The compounds terpin-4-ol (0.1-4.1\%) and eugenol (t-6.3\%) have been commonly identified in the essential oils of B. lanceolaria, H. indicum, and $T$. rhomboidea. 
Table 1. Chemical composition of the essential oil of B. lanceolaria H. indicum and T. rhomboidea.

\begin{tabular}{|c|c|c|c|c|c|c|}
\hline \multirow[b]{2}{*}{ Compound } & \multirow[b]{2}{*}{ RT } & \multirow[b]{2}{*}{ RI } & \multicolumn{3}{|c|}{$\%$ Content } & \multirow{2}{*}{$\underset{*}{\text { Identification }}$} \\
\hline & & & $\begin{array}{c}\text { B. } \\
\text { lanceolaria }\end{array}$ & $\begin{array}{c}H . \\
\text { indicum }\end{array}$ & $\begin{array}{c}T . \\
\text { rhomboidea }\end{array}$ & \\
\hline Tricyclene & 5.33 & 931 & 0.1 & - & - & RI, MS \\
\hline$\alpha$-Thujene & 5.78 & 944 & 0.1 & 1.1 & - & RI, MS \\
\hline$\alpha$-Pinene & 6.04 & 951 & 1.1 & 2.3 & - & RI, MS, CI \\
\hline Camphene & 6.38 & 961 & 0.1 & - & - & RI, MS \\
\hline Sabinene & 6.9 & 976 & 2.2 & 7.9 & - & RI, MS \\
\hline$\beta$-Pinene & 7.05 & 980 & 82.3 & - & - & RI, MS \\
\hline cis-m-Mentha-2,8-diene & 7.26 & 986 & 0.1 & - & - & RI, MS \\
\hline Myrcene & 7.49 & 993 & - & 3.8 & - & RI, MS, CI \\
\hline$m$-Mentha-1(7),8-diene & 7.55 & 995 & $\mathrm{t}$ & - & - & RI, MS \\
\hline$\alpha$-Phellandrene & 7.95 & 1006 & 0.5 & - & - & RI, MS, CI \\
\hline$\alpha$-Terpinene & 8.33 & 1017 & 0.6 & 0.5 & - & RI, MS \\
\hline$p$-Cymene & 8.42 & 1019 & $\mathrm{t}$ & $\mathrm{t}$ & - & RI, MS \\
\hline Limonene & 8.73 & 1028 & 0.1 & - & - & RI, MS,CI \\
\hline 1,8-Cineole & 8.74 & 1029 & - & 0.7 & - & RI, MS, CI \\
\hline$(Z)$ - $\beta$-Ocimene & 8.98 & 1035 & 0.1 & - & - & RI, MS \\
\hline$(E)$ - $\beta$-Ocimene & 9.37 & 1047 & 0.1 & - & - & RI, MS \\
\hline$\gamma$-Terpinene & 9.73 & 1057 & 2.5 & 1.1 & - & RI, MS,CI \\
\hline cis-Sabinene hydrate & 9.9 & 1062 & 0.5 & 0.2 & - & RI, MS \\
\hline$m$-Cymenene & 10.61 & 1082 & $\mathrm{t}$ & - & - & RI, MS \\
\hline Terpinolene & 10.83 & 1088 & 0.5 & 0.9 & - & RI, MS,CI \\
\hline Linalool & 10.99 & 1093 & 0.1 & - & - & RI, MS,CI \\
\hline trans-Sabinene hydrate & 11.05 & 1095 & 0.6 & - & - & RI, MS \\
\hline $\begin{array}{c}\text { cis-Decahydro } \\
\text { naphthalene }\end{array}$ & 11.1 & 1096 & - & 0.3 & - & RI, MS \\
\hline cis-Thujone & 11.14 & 1097 & - & - & $\mathrm{t}$ & RI, MS \\
\hline 1,3,8-p-Menthatrien & 11.16 & 1098 & $\mathrm{t}$ & - & - & RI, MS \\
\hline dehydro Sabina ketone & 11.55 & 1109 & - & - & 0.1 & RI, MS \\
\hline cis- $p$-Menth-2-en-1-ol & 11.91 & 1119 & 0.3 & - & - & RI, MS \\
\hline trans- $p$-Menth-2en-1-ol & 12.54 & 1137 & 0.1 & - & - & RI, MS \\
\hline trans-Verbenol & 12.75 & 1143 & 0.1 & - & - & RI, MS \\
\hline Menthofuran & 13.53 & 1165 & - & 2.1 & - & RI, MS \\
\hline Terpin-4-ol & 14.12 & 1182 & 4.1 & 1.9 & 0.1 & RI, MS, CI \\
\hline$\alpha$-Terpineol & 14.33 & 1188 & - & - & 0.2 & RI, MS,CI \\
\hline Methyl salicylate & 14.56 & 1195 & - & 54.3 & - & RI, MS \\
\hline Methyl chavicol & 14.66 & 1198 & - & - & 0.3 & RI, MS,CI \\
\hline cis-Piperitol & 14.84 & 1203 & 0.2 & - & - & RI, MS,CI \\
\hline trans-dihydrocarvone & 15.18 & 1213 & - & - & 1.2 & RI, MS \\
\hline trans-Piperitol & 15.28 & 1215 & 0.1 & & - & RI, MS,CI \\
\hline (Z)-Ocimenone & 16.05 & 1237 & - & 2.4 & - & RI, MS \\
\hline Thymol methyl ether & 16.11 & 1239 & $\mathrm{t}$ & - & - & RI, MS \\
\hline Pulegone & 16.21 & 1242 & $\mathrm{t}$ & - & - & RI, MS,CI \\
\hline$(E)$-Ocimenone & 16.35 & 1246 & - & 2.6 & - & RI, MS \\
\hline Cumin aldehyde & 16.54 & 1251 & 0.2 & & - & RI, MS \\
\hline Carvone & 16.85 & 1260 & 0.1 & - & - & RI, MS,CI \\
\hline$(E)$-Anethole & 18.21 & 1299 & $\mathrm{t}$ & $\mathrm{t}$ & - & RI, MS, CI \\
\hline
\end{tabular}




\begin{tabular}{|c|c|c|c|c|c|c|}
\hline Isobornyl acetate & 18.36 & 1303 & - & - & $\mathrm{t}$ & RI, MS \\
\hline Thymol & 18.58 & 1310 & 0.3 & $\mathrm{t}$ & - & RI, MS, CI \\
\hline$p$-Cymen-7-ol & 18.72 & 1314 & $\mathrm{t}$ & - & - & RI, MS \\
\hline Carvacrol & 19.07 & 1324 & 0.2 & $\mathrm{t}$ & - & RI, MS, CI \\
\hline Eugenol & 21.07 & 1381 & $\mathrm{t}$ & 6.3 & 1.0 & RI, MS, CI \\
\hline Cyclosativene & 22.54 & 1423 & - & - & 0.8 & RI, MS \\
\hline Isoledene & 22.67 & 1427 & - & - & $\mathrm{t}$ & RI, MS \\
\hline$\alpha$-copaene & 22.87 & 1432 & - & - & 0.3 & RI, MS \\
\hline$\beta$-Bourbonene & 23.08 & 1438 & - & - & 0.1 & RI, MS \\
\hline$\beta$-Elemene & 23.48 & 1450 & - & - & 0.3 & RI, MS \\
\hline Methyl eugenol & 23.8 & 1459 & - & 1.2 & - & RI, MS, CI \\
\hline Longifolene & 23.99 & 1464 & - & - & 0.5 & RI, MS \\
\hline$\alpha$-Gurjunene & 24.24 & 1471 & - & - & 0.8 & RI, MS \\
\hline$\beta$-Caryophyllene & 24.68 & 1484 & - & 0.8 & 28.9 & RI, MS, CI \\
\hline$\beta$-Gurjunene & 24.88 & 1490 & - & - & 1.7 & RI, MS \\
\hline$\gamma$-Elemene & 25.06 & 1495 & - & - & 0.7 & RI, MS \\
\hline 6,9-Guaiadene & 25.42 & 1505 & - & - & 3.6 & RI, MS \\
\hline cis-Muurola-3,5-diene & 25.63 & 1511 & - & - & 0.3 & RI, MS \\
\hline$\alpha$-Humulene & 25.77 & 1515 & - & $\mathrm{t}$ & 8.5 & RI, MS \\
\hline Sesquisabinene & 26.06 & 1523 & - & - & 2.8 & RI, MS \\
\hline 4,5-di-epi-Aristolochene & 26.5 & 1536 & - & - & 0.9 & RI, MS \\
\hline$\gamma$-Gurjunene & 26.61 & 1539 & - & - & 0.3 & RI, MS \\
\hline$(E)$ - $\beta$-Ionone & 26.73 & 1543 & - & 1.7 & - & RI, MS \\
\hline$\beta$-Selinene & 27.04 & 1551 & - & - & 2.6 & RI, MS \\
\hline $\begin{array}{l}\text { trans-Muurola-4(14), 5- } \\
\text { diene }\end{array}$ & 27.19 & 1556 & - & - & 1.7 & RI, MS \\
\hline epi-Cubebol & 27.35 & 1560 & - & - & 1.2 & RI, MS \\
\hline$\alpha$-Selinene & 27.45 & 1563 & - & - & 0.3 & RI, MS \\
\hline$\alpha$-Muurolene & 27.65 & 1569 & - & - & 0.5 & RI, MS \\
\hline Germacrene A & 27.77 & 1572 & - & - & 0.3 & RI, MS \\
\hline$\gamma$-Cadinene & 28.09 & 1581 & - & - & 1.1 & RI, MS \\
\hline cis-Calamenene & 28.21 & 1585 & - & 4.7 & - & RI, MS \\
\hline$\delta$-Cadinene & 28.25 & 1586 & - & 1.1 & 4.8 & RI, MS \\
\hline trans-Calamenene & 28.46 & 1592 & - & - & $\mathrm{t}$ & RI, MS \\
\hline trans-Cadina-1,4-diene & 28.8 & 1602 & - & - & 0.2 & RI, MS \\
\hline$\alpha$-Cadinene & 28.88 & 1604 & - & - & 6.9 & RI, MS \\
\hline$\alpha$-Calacorene & 28.93 & 1605 & - & - & 0.5 & RI, MS \\
\hline Germacrene B & 29.28 & 1615 & - & - & 1.4 & RI, MS \\
\hline cis-Muurol-5-en-4- $\alpha$-ol & 29.44 & 1620 & & - & - & \\
\hline Germacrene D-4-ol & 30.28 & 1644 & - & - & 1.0 & RI, MS \\
\hline Caryophyllene oxide & 30.37 & 1647 & - & 0.3 & 2.2 & $\mathrm{RI}, \mathrm{MS}, \mathrm{CI}$ \\
\hline epi-Cedrol & 31.54 & 1680 & - & - & 0.7 & RI, MS \\
\hline 1,10-di-epi-Cubenol & 31.72 & 1685 & - & - & 0.1 & RI, MS \\
\hline 1-epi-Cubenol & 32.18 & 1698 & - & - & 0.2 & RI, MS \\
\hline epi- $\alpha$-Cadinol & 32.65 & 1712 & - & - & 1.6 & RI, MS \\
\hline Cubenol & 32.75 & 1715 & - & - & 1.2 & RI, MS \\
\hline$\alpha$-Cadinol & 33.09 & 1724 & - & - & 5.4 & RI, MS \\
\hline cis-Calamene-10-ol & 33.26 & 1729 & - & - & 6.5 & RI, MS \\
\hline Zizanal & 34.39 & 1761 & - & - & $\mathrm{t}$ & RI, MS \\
\hline 14-hydroxy- $\alpha$-Humulene & 35.32 & 1788 & - & - & $\mathrm{t}$ & RI, MS \\
\hline
\end{tabular}




\begin{tabular}{|c|c|c|c|c|c|c|}
\hline Hexadecanoic acid & 43.99 & 2036 & - & - & 2.9 & RI, MS,CI \\
\hline Methyl linoleate & 48.86 & 2175 & - & - & 0.8 & RI, MS,CI \\
\hline Monoterpene hydrocarbons & 90.4 & 17.6 & 1.6 \\
\hline Oxygenated monoterpenes & 6.7 & 0.9 & 69.5 \\
\hline Sesquiterpene hydrocarbons & - & 6.6 & 21.5 \\
\hline Oxygenated sesquiterpene & - & 0.3 & 1.3 \\
\hline \multicolumn{2}{|c|}{ Phenyl derivatives } & 0.2 & 72.8 & 1.3 \\
\hline Oxygenated long chain hydrocarbons & - & - & 3.7 \\
\hline
\end{tabular}

$\mathrm{RT}=$ Retention Time, ${ }^{*} \mathrm{RI}=$ Retention index relative to $\mathrm{C}_{8}-\mathrm{C}_{25} n$-alkanes on BP-1 column, MS=NIST and Wiley library and the literature, $\mathrm{t}=$ trace $(<0.1 \%), \mathrm{CI}=\mathrm{Co}-$ injection of commercial samples.

The essential oil constituents of B. lanceolaria growing in the Western Ghats region of India has somehow resembled the plant grown in Vietnam and other regions of India. The chemical constituents of the plant $B$. lanceolaria from Vietnam viz., $\alpha$-thujene $(0.04 \%), \alpha$-pinene $(0.01 \%)$, camphene $(0.01 \%), \beta$-pinene $(0.01 \%), \alpha$-terpinene $(0.01 \%), p$-cymene $(3.28 \%)$, limonene $(0.12 \%)$, methyl thymol $(94.96 \%)$, and $\beta$ caryophyllene $(0.04 \%)$ have been common to this report in quantitative divergence and methyl carvacrol $(0.02 \%)$ and 1-hexadecanol $(0.79 \%)$ which were reported from Vietnam [8] are not detected in this report. The rest of the compounds identified in this report are not identified in Vietnam grown B. lanceolaria (Table 1). Similarly, the only compound $p$-cymene (99\%) has been reported from India in the very high amount [7] and this report this compound has been identified in trace $(<0.1 \%)$.

A comparison of essential oil constituents of $H$. indicum of this study with the compounds of plant growing in Thailand [19] was found to be completely different. Apart from this, the report from Nigeria grown $H$. indicum plant only three compounds viz., methyl salicylate $(1.2 \%),(E)-\beta$-ionone $(1.9 \%)$ and eugenol $(2.4 \%)$ [20] were found to be common compared to the present study.

The essential oil constituents reported [21] from the aerial parts of T. rhomboidea in terms of the major compound was similar to that found in this study with quantitative differences, while qualitatively relative amounts of the components which are somehow dissimilar from France growing plant. Correlation of the compounds from France growing plant with this study revealed that a high amount of $\beta$-caryophyllene and low amount of caryophyllene oxide were found in raw seeds oil of $T$. rhomboidea. It is interesting to note that the compound kessane which was the second major compound from France growing T. rhomboidea could not be detected even trace amount in the raw seed oil in this study. Overall, out of fifty compounds identified in the raw seeds of $T$. rhomboidea, twenty-one compounds were found to be similar with varying quantities as compared to the aerial parts of France growing T. rhomboidea plant [21]. Interestingly, the cumulative quantity of twenty-one similar constituents of raw seeds and aerial parts contains more or less similar quantities $(65.4 \%$ from $T$. rhomboidea raw seeds oil and $65.7 \%$ from aerial parts $T$. rhomboidea oil.

The compound $\beta$-pinene possesses various biological activities viz., anti-infectious bronchitis virus [32], antinociceptive [33], antimicrobial [34] as well as antiviral against herpes simplex virus [35] and $\beta$-pinene present in high amount in the leaves of $B$. lanceolaria may support the traditional uses of this herb for the treatment of bronchitis, aphthae, asthma [5], wound healing, chronic ulcers, and to control dysentery [6].

The compound methyl salicylate in a small amount has been used as a topical counterirritant for the treatment of mild aches and pains of arthritis, as well as for acute muscle strain associated with the "weekend warrior" syndrome [36]. Hence, the plant $H$. indicum used as local application support traditional medicine.

The $\beta$-caryophyllene is the main compound of the essential oil of $T$. rhomboide $a$ and $\beta$-caryophyllene has anti-inflammatory [37], anticancer [38], antinociceptive [39], cytoprotective [40], analgesic [38,41] and showed marked protective [42] effects. The $\beta$-caryophyllene is an excellent therapeutic agent and the use of $T$. rhomboidea in traditional medicine may attribute to the treatment of various ailments like the treatment of cancer, diarrhea, gonorrhea to stop the burning caused by urine, treatment of anemia, relieve labor pain, etc.

The quantitative and qualitative divergence may be due to the geographical, climatic, and soil conditions, which in turn may affect the composition and other secondary metabolites of the plants $[43,44]$. Essential oil formation in the plants is highly dependent on climatic conditions, especially day length, 
irradiance, temperature, and water supply. Tropical species follow in their vegetation cycle the dry and rainy seasons, while species of the temperate zones react more on day length, the more distant from the equator their natural distribution area is located [45]. The ecological experiments regard to the essential oil content was found a correlation between flower formation, flowering period, and essential oil synthesis [45]. It was observed that the shorter the flowering phase, the less was the time available for oil formation, and thus the lower oil content. The composition of the essential oil, on the other hand, showed no qualitative change due to ecological or climatic factors confirming that chemotypes keep their typical pattern [45].

\section{Conclusion}

The present investigation concludes that the essential of $H$. indicum collected from south India was found to be methyl salicylate chemotype. Hence, $H$. indicum could be a good source of methyl salicylate, which is the main constituent of the oil. In conclusion, the essential oil constituents vary in plant parts as well as in different localities growing plants. The plant $T$. rhomboidea is a high valued medicinal plant and as per the geoclimatic distribution of the flora, botanicals are consumed by the people as their own localities to cure the diseases. Secondary metabolites of the plants are changes in quantity or produced different chemotypes which may alter the biological activities. This study revealed that qualitative and quantitative difference in case of $B$. lanceolaria oil and compared from the previous reports, could exhibit altered bioactivities. Further studies are required to investigate the biological activities of the volatile constituents of these plants.

\section{Acknowledgments}

The author is grateful to the Indian Council of Medical Research (ICMR), New Delhi, India for providing the necessary facilities, and is thankful to Mr. Mahesh B. Wagarwadi, Multi Tasking Staff (MTS), Department of Phytochemistry, ICMR-NITM, Belagavi for processing and extraction of the oils.

\section{References}

1. Wachtel-Galor, S.; Benzie, I.F.F., in: Herbal Medicine, Benzie, I.F.F., Wachtel-Galor, S., Eds., CRC Press, Taylor and Francis, Boca Raton, FL, 2011.

2. Chamorro, E.R.; Zambon, S.N.; Morales, W.G.; Sequeira, A.F.; Velasco, G.A., in: Study of the Chemical Composition of Essential Oils by Gas Chromatography, Gas Chromatography in Plant Science, Wine Technology, Toxicology and Some Specific Applications, Salih, B., Ed. In Tech, 2012.

3. Joshi, R.K., in: A Perspective on the Phytopharmaceuticals Responsible for the Therapeutic Applications, eds. Keservani, R.K., Sharma, A. K., Keservani, R. K., IGI Global, Pennsylvania, USA, 2017.

4. Myers, N.; Mittermeier, R.A.; Mittermeier, C.G.; Gustavo, A.B.; Fonseca, D.A.; Kent, J., Nature 2000, 403, 853-858.

5. Uphof, J.C.T., in: Dictionary of Economic Plants, Engelmann, H. R., Cramer, J., Eds., New York, USA, 1959.

6. Rai, P. K.; Lalramnghinglova, H., Ethnobot. Leaflets 2010, 6, 2010.

7. Dutta, S. C.; Saha, B. N.; Pathak, M. G.; Mathur, R. K., Indian Perfum. 1989, 33, 38-39.

8. Dung, N. X.; Loi, D. T.; Hung, D. T.; Leclercq, P. A., J. Essent. Oil Res. 1991, 3, 285-286.

9. Khare, C. P., in: Indian Medicinal Plants, An Illustrated Dictionary, Springer Science, SpringerVerlag, 2007.

10. Mattocks, A. R.; Schoental, R.; Crowley, H. C.; Culvenor, C. C. J., J. Chem. Soc. 1961,1064, 54005403. 
11. Dash, G. K.; Murthy, P. N., ISRN Pharmacol. 2011, 1-8.

12. Reddy, J. S.; Rao, P. R.; Reddy, M. S., J. Ethnopharmacol. 2002, 79, 249-251.

13. Adelaja, A. A.; Ayoola, M. D.; Otulana, J. O., Akinola, O. B.; Olayiwola, A.; Ejiwunmi A. B.; Malays. J. Med. Sci. 2008, 15, 22-30.

14. Srinivas, K.; Rao, M. E. B.; Rao, S.S., Indian J. Pharmacol. 2000, 32, 37-38.

15. Mattocks, A. R., J. Chem. Soc. 1967, 329-331.

16. Souza, J. S. N.; Machado, L. L.; Pessoa, O. D. L.; Braz-Filho, R.; Overk, C.R.; Yao, P.; Cordell, G. A.; Lemos, T. L. G., J. Braz. Chem. Soc. 2005, 16, 1410-1414.

17. Yeo, D.; Attioua, B.; Lehalle, C.; Kossi, M.; Nguessan, J. D.; Djaman, A. J.; Lobstein, A.; Frossard, N., J. Appl. Pharm. Sci. 2011, 01, 102-106.

18. Dutta, S. K., Sanyal, U.; Chakraborty, S. K., Indian J. Cancer Chemother. 1987, 9, 73-77.

19. Machan, T.; Korth, J.; Liawruangrath, B.; Liawruangrath, S.; Pyne, S. G., Flavour Fragr. J. 2006, 21 , 265-267.

20. Ogunbinu, A. O.; Flamini, G.; Cioni, P. L.; Adebayo, M. A.; Ogunwande, I.A., Nat. Prod. Commun. 2009, 4, 573-578.

21. Mevy, J. P., Bessiere, J. M.; Rabier, J.; Dherbomez, M.; Ruzzier, M., Millogo, J.; Viano, J., Flavour Fragr. J. 2006, 21, 80-83.

22. Sivakumar, P.; Sambath, K. R., Sivakumar, T., Nethaji, R.; Vijayabaskaran, M.; Perumal, P.; Bukkawer, A. R.; Jayakar, B.; Parvathi, K.; Sarasu, C., Res. J. Med. Sci. 2008, 2, 203-208.

23. Tchoukoua, A.; Sandjo, L. P.; Keumedjio, F.; Ngadjui, B. T., Kirsch, G., Chem. Nat. Compd. 2013, 49, 811-814.

24. Lissy, K. P.; Simon, T. K.; Lathab, M. S., Anc. Sci. Life 2006, 25, 10-15.

25. Joshi, R. K., Nat. Prod. Commun. 2018, 13, 1355-1356.

26. Joshi, R. K., Chem. Nat. Compd. 2018, 54, 584-585.

27. Sharma, S.; Rasal, V. P.; Joshi, R. K.; Patil, P. A., Indian J. Pharm. Sci. 2018, 80, 383-390.

28. Joshi, R. K.; Pai, S. R., Nat. Prod. Res. 2016, 30, 2368-2371.

29. Joshi, R. K., Nat. Prod. Res. 2016, 30, 979-981.

30. Joshi, R. K., Chem. Nat. Compd. 2018, 54, 377-379.

31. Joshi, R. K., J. Chromatogr. Sci. 2016, 54, 295-298.

32. Yang, Z.; Wu, N.; Zu, Y.; Fu, Y., Molecules 2011, 16, 1044-1054.

33. Liapi, C.; Anifandis, G.; Chinou, I.; Kourounakis, A. P.; Theodosopoulos, S.; Galanopoulou, P., Planta Med. 2007, 73, 1247-1254.

34. Liao, S.; Shang, S.; Shen, M.; Rao, X.; Si, H.; Song, J.; Song, Z., Bioorg. Med. Chem. Lett. 2016, 26, 1512-1515.

35. Astani, A.; Schnitzler, P., Iran J. Microbiol. 2014, 6, 149-155.

36. Martin, D.; Valdez, J.; Boren, J.; Mayersohn, M., J. Clin. Pharmacol. 2004, 44, 1151-1157.

37. Andrade-Silva, M.; Correa, L. B.; Candea, A. L.; Cavalher-Machado, S. C.; Barbosa, H. S.; Rosas, E. C., Henriques, M. G., Inflamm. Res. 2016, 65, 869-879.

38. Fidyt, K.; Fiedorowicz, A.; Strządała, L.; Szumny, A., Cancer Med. 2016, 5, 3007-3017.

39. Ghelardini, C.; Galeotti, N.; Di Cesare, M. L.; Mazzanti, G.; Bartolini, A., Farmaco. 2001, 56, 387389.

40. Assis, L. C.; Straliotto, M. R.; Engel, D.; Hort, M. A.; Dutra, R. C.; de Bem, A. F., Neuroscience 2014, 279, 220-231.

41. Klauke, A. L.; Racz, I.; Pradier, B.; Markert, A.; Zimmer, A. M., Gertsch, J.; Zimmer, A., Eur. Neuropsychopharmacol 2014, 24, 608-620.

42. Kelany, M. E.; Abdallah, M. A., Can. J. Physiol. Pharm. 2016, 94, 739-744.

43. Joshi, R. K., Natl. Acad. Sci. Lett. 2013, 36, 349-352.

44. Joshi, R. K., Natl. Acad. Sci. Lett. 2014, 37, 331-333.

45. Franz, C.; Novak, J., in: Sources of essential oils in: Handbook of Essential Oils Science, Technology, and Applications, Baser, K. H. C., Buchbauer, G., Eds. CRC Press, New York, NY, USA, 2010. 